\title{
MANAJEMEN PERUBAHAN DALAM \\ TEKNOLOGI INFORMASI DAN KOMUNIKASI (TIK) PEMERINTAHAN DI INDONESIA Sebuah Pemikiran Dalam Menyongsong Peralihan e-Government Menjadi e-Governance
}

\author{
T. Fahrul Gafar \\ Program Studi Ilmu Pemerintahan \\ Fakultas Ilmu Sosial dan Ilmu Politik, Universitas Abdurrab \\ email: gaffar@univrab.ac.id
}

\begin{abstract}
ABSTRAK
Selama lebih dari satu dekade program e-Government atau penggunaan dan pemanfaatan Teknonogi Informasi dan Komunikasi (TIK) di Indonesia diimplementasikan sejak dikeluarkannya Instruksi Presiden (Inpres) no 3 Tahun 2003 tentang Kebijakan dan Strategi Nasional Pengembangan e-Government indonesia. Namun, selama itu pula kinerja $e$ Government Indonesia belum menemui performa yang ideal. Sebuah fakta dan data menyatakan, bahwa pada tahun 2016 Indonesia mendapat peringkat ke 116 dunia versi $e$ Government Development Index (EGDI), turun 10 peringkat dibandingkan tahun 2014 yang menduduki peringkat ke 106. Kondisi ini masih jauh berada di bawah negara-negara di Asia Tenggara lainnya seperti Singapura (peringkat ke-4), Malaysia (peringkat ke-60), Filipina (peringkat ke-71), dan Brunei Darussalam (peringkat ke-83). Sementara itu, nilai Online Service Index (OSI), dan Telecommunication Infrastructure Index (TII) Indonesia juga masih berada di bawah rata-rata di regional Asia. Indonesia berada pada angka 0,3623 pada OSI, dan 0,3016 pada TII, sedangkan di kawasan Asia rata-rata OSI pada angka 0,5120 dan TII pada angka 0,3730. Melalui tulisan ini, penulis berupaya menawarkan beberapa gagasan dengan mengikuti rentak dan ritme kemunculan teori-teori baru dalam ilmu pengetahuan, bahwa nampaknya pemerintah tidak bisa diharapkan lagi menjadi pemain atau agen tunggal dalam program pengembangan e-Government, melainkan sinergitas satu dari empat pemain yang mengitari orbit besar bernama governance (penata-kelolaan) bersama-sama dengan pihak swasta yang memiliki kreatifitas, kalangan universitas-akademisi/ profesional yang memiliki ide dan gagasan cerdas, serta masyarakat secara luas, sehingga pemerintah sang pemilik otoritas mampu menjamin terlaksananya semua hajatan dengan tuntas dan dengan hasil yang pantas.
\end{abstract}

Kata Kunci: Manajemen Perubahan, Teknologi Informasi dan Komunikasi (TIK), $e$ Government, e-Governance, Indonesia 


\begin{abstract}
ASBTRACT
For more than a decade the program e-Government or use and utilization of Teknonogi Information and Communication Technology (ICT) in Indonesia implemented since the issuance of the Presidential Instruction (Presidential Instruction no 3 of 2003 on the National Strategy and Policy Development of e-Government of Indonesia. But then the performance of the e-Government Indonesia has not yet found an ideal performance. A fact and data stated that in the year 2016 Indonesia rated to 116 world version e-Government Development Index (EGDI), down 10 stages compared to the year 2014 which ranked to 106. This condition is still far under the countries in Southeast Asia such as Singapore (stages the 4), Malaysia (60th stage), the Philippines (stages to-71), and Brunei Darussalam (ranked 83th birthday). Meanwhile, the value of the Online Service Index (OSI), and Telecommunication Infrastructure Index (BAWAH) Indonesia also is still below the regional average of Asia. Indonesia is located on numbers 0,3623 on OSI, and 0,3016 on Transparency International Indonesia, while in the Asian region the average OSI on numbers 0,5120 and Transparency International Indonesia on numbers 0,3730. Through this writing, author attempt to offer some ideas to follow rentak and rhythm of the emergence of new theories in science that seems to the government cannot be expected to again be a player or single agent in e-Government development program, but sinergitas one of four players going around the large orbit named governance (styler-kelolaan) together with private parties who have creativity, among universities academics/ professionals who have the ideas and the idea of smartphone, and society widely, so that the government of the owner the authority is able to guarantee the implementation of all celebration with unrest and with the result that deserves.
\end{abstract}

Keywords: management of transformation; information and communication technology; $e$ Government; e-Governance; Indonesia

\section{PENDAHULUAN}

Sebagai manusia, kita hidup dalam sebuah kosmos yang teratur dan rapi, berubah dan berpindah mengikuti hukum dan peraturan alam yang disiplin dan tepat waktu. Perubahan merupakan suatu hal yang pasti terjadi dan akan terjadi pada rantai kontinum sejarah umat manusia sejak zaman bermula hingga sekarang. Hal itu dapat diungkapkan dengan kata-kata "panta rei" (dalam Bahasa Belanda: "alles verandert" dan dalam Bahasa inggris: "everything change"). Dengan meresapi makna tersebut berarti manusia harus senantiasa berubah sesuai dengan tuntutan perubahan itu sendiri.

Sebagaimana layaknya manusia, teknologi pun mengalami perubahan dan perkembangan yang sangat pesat, merambah semua aspek dan sendi kehidupan manusia termasuk dalam bidang telekomunikasi, yakni suatu teknik pengiriman atau penyampaian infomasi dari suatu tempat ke tempat lain sebagai bentuk komunikasi dua arah jarak jauh secara berkesinambungan. 
Berkaca pada keadaan manusia dan teknologi sebagaimana diatas, pemerintahan juga merupakan sebuah proses perubahan. Proses tersebut bekerja dan bereaksi dalam lingkungan yang senantiasa berubah. Tetapi tentunya peristiwa perubahan pemerintahan berbeda dengan teknologi, baik itu cara, alat, maupun lingkungan yang mudah berubah dan mudah diubah. Pemerintahan memiliki komponen dan nilai yang sukar berubah atau sulit diubah, yaitu kekuasaan, kepentingan, monopoli, dan kenikmatan. Pada segmen itu, pemerintahan bisa bergesekan bahkan bertabrakan dengan nilai-nilai yang berkembang dalam dunia teknologi seperti teknokrasi, profesionalisme, meritokrasi dan lainnya. Namun disisi lain, terdapat juga segmen pemerintahan yang nilai-nilainya justru memerlukan perubahan secara berkesinambungan dikarenakan sasarannya yang unik dan selalu berubah-ubah. Pada keadaan tersebut Ndraha (2003:539) menyatakan bahwa disitulah terjadinya persentuhan antara pemerintahan dengan seni dan teknik. Sentuhan seni dalam pemerintahan melahirkan seni pemerintahan dan sentuhan teknologi melahirkan teknonogi pemerintahan yang kini dikenal dengan sebutan $e$ Geovernment.

Terminologi e-Government yang kini kita kenal merupakan perkembangan mutakhir teknologi informasi dalam bidang pemerintahan yang pada awalnya berasal dari filosofi kerja Sistem Infomasi Manajemen (SIM). Pada mulanya, SIM dijalankan oleh manusia secara manual dengan pengertian bahwa SIM adalah sekumpulan informasi (fakta tercatat, catatan tersebut dinamai dengan data, dan data yang diolah disebut informasi) yang ter-manage/teratur secara sistematis. Namun lagi-lagi dengan adanya persentuhan dari anasir lain dalam hal ini adalah teknologi, yaitu perangkat-perangkat Teknologi Informasi dan Komunikasi (TIK), sehingga secara utuh dan penuh SIM dapat diartikan sebagai sebuah sistem manusia dan mesin secara terpadu (integrated system) untuk menyajikan informasi guna mendukung fungsi operasi, manajemen, dan pengambilan keputusan dalam organisasi, dan SIM merupakan serangkaian sub sistem informasi yang menyeluruh dan terkoordinasi secara rasional dan terpadu yang mampu mentransformasi data sehingga menjadi informasi lewat serangkaian cara guna meningkatkan produktivitas yang sesuai dengan gaya dan sifat manajer atas dasar kriteria mutu yang telah ditetapkan. Sebagai ilustrasi, alur perubahan terjadi pada narasi diatas, dapat kita lihat melalui kontinum sebagai berikut : $\mathrm{SIM} \rightarrow \mathrm{TIK} \rightarrow e$-Government. Dari fase inilah diperlukan sebuah manajemen 
perubahan dalam rangka mengatur ritme perubahan yang terjadi dalam dunia pemerintahan yang sangat dinamis.

$$
\text { Hingga tahun 2015, }
$$

berdasarkan data terakhir yang dapat dilihat pada laman web PeGI (http://pegi.layanan.go.id/), pemerintah Republik Indonesia telah melakukan penilaian terhadap pengembangan $e$ Government pada setiap Kementrian, Lembaga Pemerintah Non Kementrian (LPNK), dan juga Provinsi di Indonesia yang diistilahkan dengan Pemeringkatan e-Government Indonesia (PeGI). Melalui Pemeringkatan e-Government Indonesia, setiap Kementrian, LPNK, dan Pemerintah Daerah mendapatkan penilaian yang dilakukan oleh Kementerian Kominfo sebagai bahan evaluasi bagi Pemerintah Pusat dalam pengembangan e-Government Indonesia selanjutnya.

Sementara di tingkat dunia, Persekutuan Bangsa-Bangsa (PBB) juga telah melakukan Indexing atau pemeringkatan e-Government Sejak tahun $2003 \quad$ (E-Government Development Index-disingkat EGDI) sebagai dasar pemeringkatan negaranegara yang menjadi anggota PBB. EGDI adalah indikator komposit yang mengukur kemauan dan kapasitas administrasi pemerintahan untuk menggunakan TIK dalam menyediakaan dan memberikan layanan kepada publik. Yang menjadi dasar pembahasan dalam tulisan ini adalah EGDI terkini yaitu edisi 2014 dan 2016 berdasarkan tiga sub index yaitu Online Service Index (OSI), Telecommunication Infrastructuture Index (TII), dan Human Capital Index (HCI).

Pada tahun 2016 Indonesia mendapat peringkat ke 116 versi $E$ Government Development Index (EGDI) atau turun 10 peringkat dibandingkan tahun 2014 yang menduduki peringkat ke 106. Kondisi ini masih jauh berada di bawah negaranegara di Asia Tenggara seperti Singapura (peringkat ke-4), Malaysia (peringkat ke-60), Filipina (peringkat ke-71), dan Brunei Darussalam (peringkat ke-83). Sementara itu, nilai Online Service Index (OSI) dan Telecommunication Infrastructure Index (TII) Indonesia juga masih berada di bawah rata-rata di regional Asia. Indonesia berada pada angka 0,3623 OSI dan 0,3016 TII, dan sedangkan di kawasan Asia rata-rata OSI pada angka 0,5120 , TII pada angka 0,3730 dan HCI pada angka 0.6545 . Selengkapnya dapat kita lihat pada tabel 1, 2, dan 3 dibawah ini: 
Tabel 1. Perbandingan Rangking E-Government Development Index (EGDI) 2014 \& 2016

\begin{tabular}{|c|l|c|c|l|c|}
\hline $\begin{array}{c}\text { No } \\
\text { Urut }\end{array}$ & Negara & $\begin{array}{c}\text { Rangking } \\
(\mathbf{2 0 1 4 )}\end{array}$ & $\begin{array}{c}\text { No } \\
\text { Urut }\end{array}$ & \multicolumn{1}{|c|}{ Negara } & $\begin{array}{c}\text { Rangking } \\
(\mathbf{2 0 1 6})\end{array}$ \\
\hline 1 & Singapura & 3 & 1 & Singapura & 4 \\
\hline 2 & Malaysia & 52 & 2 & Malaysia & 60 \\
\hline 3 & Brunei Darussalam & 86 & 3 & Filipina & 71 \\
\hline 4 & Filipina & 95 & 4 & Thailand & 77 \\
\hline 5 & Vietnam & 99 & 5 & $\begin{array}{l}\text { Brunei } \\
\text { Darussalam }\end{array}$ & 83 \\
\hline 6 & Thailand & 102 & 6 & Vietnam & 89 \\
\hline $\mathbf{7}$ & Indonesia & $\mathbf{1 0 6}$ & $\mathbf{7}$ & Indonesia & $\mathbf{1 1 6}$ \\
\hline 8 & Kamboja & 139 & 8 & Laos & 148 \\
\hline 9 & Laos & 152 & 9 & Kamboja & 158 \\
\hline 10 & Timor Leste & 161 & 10 & Timor Leste & 160 \\
\hline 11 & Myanmar & 175 & 11 & Myanmar & 169 \\
\hline
\end{tabular}

Sumber : Data Hasil Olahan (United Nations E-Government Survey 2016, e-Government in Support of Sustainable Development $)^{1}$.

\footnotetext{
${ }^{1}$ Lihat juga di http://workspace.unpan.org/sites/Internet/Documents/UNPAN96407.pdf
} 
Tabel 2. Rangking E-Government Development Index (EGDI) 2014

\begin{tabular}{|c|c|c|c|c|c|c|}
\hline $\begin{array}{c}\text { Rangking } \\
\text { (Asteng) }\end{array}$ & Negara & $\begin{array}{c}\text { Rangking } \\
\text { (Dunia) }\end{array}$ & EDGI & $\begin{array}{l}\text { Online } \\
\text { Service } \\
\text { Index } \\
\text { (OSI) }\end{array}$ & $\begin{array}{c}\text { Telecomm. } \\
\text { Infrastructure } \\
\text { Index } \\
\text { (TII) }\end{array}$ & $\begin{array}{c}\text { Human } \\
\text { Capital } \\
\text { Index } \\
\text { (HCI) }\end{array}$ \\
\hline 1 & Singapura & 4 & 0.8828 & 0.9710 & 0.8414 & 0.8360 \\
\hline 2 & Malaysia & 60 & 0.6175 & 0.7174 & 0.4397 & 0.6953 \\
\hline 3 & Filipina & 71 & 0.5765 & 0.3791 & 0.6667 & 0.6839 \\
\hline 4 & Thailand & 77 & 0.5522 & 0.5507 & 0.4117 & 0.6942 \\
\hline 5 & Brunei D & 83 & 0.5298 & 0.5072 & 0.3512 & 0.7310 \\
\hline 6 & Vietnam & 89 & 0.5143 & 0.5725 & 0.3715 & 0.5989 \\
\hline 7 & Indonesia & 116 & 0.4478 & 0.3623 & 0.3016 & 0.6796 \\
\hline 8 & Laos & 148 & 0.3090 & 0.2826 & 0.1537 & 0.4907 \\
\hline 9 & Kamboja & 158 & 0.2593 & 0.0507 & 0.2486 & 0.4785 \\
\hline 10 & $\begin{array}{l}\text { Timor } \\
\text { Leste }\end{array}$ & 160 & 0.2582 & 0.2174 & 0.0728 & 0.4843 \\
\hline 11 & Myanmar & 169 & 0.2362 & 0.1594 & 0.0655 & 0.4837 \\
\hline \multicolumn{3}{|c|}{ Rata-rata Asia } & 0.5132 & 0.5120 & 0.3730 & 0.6545 \\
\hline \multicolumn{3}{|c|}{ Rata-rata Dunia } & 0.4922 & 0.4623 & 0.3711 & 0.6433 \\
\hline
\end{tabular}

Sumber: Data Hasil Olahan (UNITED NATIONS e-Government SURVEY 2014 e-Government for The futre we want $)^{2}$.

${ }^{2}$ Lihat juga di https://publicadministration.un.org/egovkb/Portals/egovkb/Documents/un/2014-

Survey/E- Gov_Complete_Survey-2014.pdf 
Tabel 3. Rangking E -Government Development Index (EGDI) 2016

\begin{tabular}{|c|c|c|c|c|c|c|}
\hline $\begin{array}{l}\text { Rangking } \\
\text { (Asteng) }\end{array}$ & Negara & $\begin{array}{c}\text { Rangking } \\
\text { (Dunia) }\end{array}$ & EDGI & $\begin{array}{l}\text { Online } \\
\text { Service } \\
\text { Index } \\
\text { (OSI) }\end{array}$ & $\begin{array}{l}\text { Telecomm. } \\
\text { Infrastructure } \\
\text { Index } \\
\text { (TII) }\end{array}$ & $\begin{array}{c}\text { Huan } \\
\text { Capital } \\
\text { Index } \\
\text { (HCI) }\end{array}$ \\
\hline 1 & Singapura & 3 & 0.9076 & 0.9921 & 0.8793 & 0.8515 \\
\hline 2 & Malaysia & 52 & 0.6115 & 0.6772 & 0.4455 & 0.7119 \\
\hline 3 & Brunei D & 86 & 0.5042 & 0.3622 & 0.3690 & 0.7815 \\
\hline 4 & Filipina & 95 & 0.4768 & 0.4803 & 0.2451 & 0.7051 \\
\hline 5 & Vietnam & 99 & 0.4705 & 0.4173 & 0.3792 & 0.6148 \\
\hline 6 & Thailand & 102 & 0.4631 & 0.4409 & 0.2843 & 0.6640 \\
\hline 7 & Indonesia & 106 & 0.4487 & 0.3622 & 0.3054 & 0.6786 \\
\hline 8 & Kamboja & 139 & 0.2999 & 0.1732 & 0.2075 & 0.5189 \\
\hline 9 & Laos & 152 & 0.2659 & 0.1417 & 0.1618 & 0.4941 \\
\hline 10 & $\begin{array}{l}\text { Timor } \\
\text { Leste }\end{array}$ & 161 & 0.2528 & 0.2047 & 0.0704 & 0.4941 \\
\hline 11 & Myanmar & 175 & 0.1869 & 0.0236 & 0.0084 & 0.5288 \\
\hline \multicolumn{3}{|c|}{ Rata-rata Asia } & 0.4951 & 0.4652 & 0.3584 & 0.6615 \\
\hline \multicolumn{3}{|c|}{ Rata-rata Dunia } & 0.4712 & 0.3919 & 0.3650 & 0.6566 \\
\hline
\end{tabular}

Sumber: Data Hasil Olahan (United Nations E-Government Survey 2016, e-Government in Support of Sustainable Development) $)^{3}$.

Data-data yang termaktub diatas merupakan catatan dari EGDI (E-Government Development Index) yang didasarkan pada survei menyeluruh tentang kehadiran pemerintah secara online dari semua (193) Negara anggota Perserikatan Bangsa-Bangsa (PBB) dimana EGDI menilai situs web nasional sebuah negara dan bagaimana kebijakan serta strategi e-Government dinegara tersebut diterapkan secara umum dan secara spesifik pada sektor-sektor tertentu dalam penyampaian layanan kepada publiknya. Penilaian kinerja $e$ Government negara-negara tersebut relatif terhadap satu sama lain dan hasilnya ditabulasikan serta dikombinasikan dengan seperangkat indikator yang mewujudkan

\footnotetext{
${ }^{3}$ Lihat juga di http://workspace.unpan.org/sites/Internet/Documents/UNPAN96407.pdf
} 
kemampuan suatu negara untuk berpartisipasi dalam masyarakat informasi. Adapun yang menjadi acuan terhadap indikator-indikator survei EGDI (E-Government Development Index) adalah :

1. Very High-EGDI (Greater than 0.75)

2. High-EGDI (Between 0.50 and $0.75)$

3. Middle/Medium-EGDI (Between 0.25 and 0.50)

4. Low-EGDI (Less than 0.25)

Berdasarkan pada sumber diatas, data pada tabel 1, 2, dan 3 menunjukkan bahwa posisi indonesia walaupun tidak merubah kedudukannya pada posisi ke 7 negaranegara Asia Tenggara, namun apabila diperhatikan pada indikator Online Service Index

(OSI),

Telecommunication Infrastructure Index (TII) masih berada dibawah ratarata kecuali pada indikator Human Capital Index (HCI) saja yang berada pada angka cukup memuaskan. Namun secara keseluruhan Indonesia masih berada dibawah rata-rata Asia dan Dunia yaitu berada pada kategori ke 3 atau Middle/Medium-EGDI, pada kisaran $0.25-0.50$ berdasarkan laporan United Nations e-Government Survey 2016 (E-Government In Support Of Sustainable Development). Tentunya catatan ini harus menjadi perhatian semua pihak dan bukan hanya penyelenggara Negara saja, karena penggunaan dan pemanfaatan Teknologi Informasi dan Komunikasi (TIK) atau e-Government secara professional dan proporsional ternyata juga berkorelasi dengan kualitas Sumber Daya Manusia sebuah Negara, sehingga semua pihak (actor) harus bersinergi.

\section{PEMBAHASAN}

\section{Diorama Teknologi Informasi dan Komunikasi (TIK) Pemerintahan di Indonesia}

Pada tahun 2003, Presiden Indonesia mengeluarkan Instruksi Presiden Nomor 3 Tahun 2003 tentang Kebijakan dan Strategi Nasional Pengembangan e-Government. Kemunculan Inpres ini tidak saja diartikan sebagai tindak lanjut Inpres Nomor 6 Tahun 2001 tentang Pengembangan dan Pendayagunaan Telematika Indonesia, tetapi juga merupakan cetusan komitmen untuk menerapkan sebuah konsep tentang pemanfaatan teknologi informasi yang telah dipraktekkan di negara-negara maju yang telah melahirkan sebuah bentuk mekanisme birokrasi pemerintahan yang efektif dan efisien, yang diistilahkan sebagai Electronic Government (e-Government).

Secara tegas, Inpres Nomor 3 tahun 2003 merumuskan bahwa tujuan pengembangan e-Government merupakan upaya untuk mengembangkan penyelenggaraan 
kepemerintahan yang berbasis (menggunakan) perangkat elektronik dalam rangka meningkatkan kualitas layanan publik secara efektif dan efisien. Pencapaian tujuan strategis $e$ Government perlu dilaksanakan melalui 6 (enam) strategi yang berkaitan erat, yaitu :

1. Mengembangkan sistem pelayanan yang andal dan terpercaya, serta terjangkau oleh masyarakat luas.

2. Menata sistem manajemen dan proses kerja pemerintah dan pemerintah daerah otonom secara holistik.

3. Memanfaatkan teknologi informasi secara optimal.

4. Meningkatkan peran serta dunia usaha dan mengembangkan industri telekomunikasi dan teknologi informasi.

5. Mengembangkan kapasitas SDM baik pada pemerintah maupun pemerintah daerah otonom, disertai dengan meningkatkan e-literacy masyarakat.

6. Melaksanakan pengembangan secara sistematik melalui tahapan-tahapan yang realistik dan terukur.

Dalam perkembangannya, sebagian besar pengembangan $e$ Government yang ada pada saat ini masih terfokus pada penyediaan web site dan layanan informasi saja, sehingga mendorong munculnya anggapan bahwa suatu instansi pemerintah sudah menerapkan $e$ Government ketika sudah memiliki website. Padahal e-Government tidak hanya menampilkan informasi pemerintahan melalui website semata, namun lebih dari itu, yakni adanya tranformasi hubungan antara pemerintah dengan seluruh stakeholder yang semula menggunakan media konvensional digantikan dengan media elektronik secara online (internet).

\section{Pemanfataan e-Government} bagi pemerintah adalah untuk menciptakan pelayanan yang efektif dan efisien. Efektifitas dan efisiensi dari pemerintah dapat dianalogikan sebagai berikut; jika dahulu sebuah pemerintah terkenal dengan birokrasinya yang sangat lambat, boros, dan sangat fungsional, maka masyarakat saat ini membutuhkan sebuah kinerja pemerintah yang cepat, murah, dan berorientasi pada proses agar dapat memberikan dukungan yang signifikan dan kompetitif bagi para customer-nya (individu, komunitas bisnis, masyarakat, dan stakeholder yang lain). Tentu saja merubah paradigma tersebut bukanlah merupakan suatu hal yang mudah namun disisi lain perubahan merupakan suatu keharusan bukan pilihan, dan bagi siapa yang dapat melakukan perubahan secara cepat akan semakin diuntungkan karena selain dapat beradaptasi dengan 
lingkungan yang baru, yang bersangkutan dapat menjadi pemain kunci dalam mekanisme global tersebut.

Di tingkat daerah, pemerintah daerah juga dituntut untuk mengikuti roadmap yang telah ditentukan oleh pemerintah Republik Indonesia melalui kementerian Informasi dan Komunikasi (Kominfo) sebagai kementerian yang memiliki kewenangan dan bertanggung jawab terhadap pengembangan $e$ Government Indonesia. Berdasarkan roadmap Kementrian Kominfo, pada tahap pertama atau tahun 2010-2012, merupakan fase Indonesia Connected, dimana dalam tahap ini seluruh desa ada akses telepon, seluruh kecamatan harus ada akses internet. Pada tahap kedua atau tahun 2012-2014 Kemkominfo memiliki misi Indonesia Informative, yaitu masyarakat Indonesia sudah masuk dalam masyarakat Informasi. Pada fase ini, diharapkan seluruh ibukota propinsi terhubung dengan jaringan fiber optic (serat optik), seluruh kabupaten/kota memilik akses broadband dan peningkatan e-Service, e-Health, eEducation dan "e" lainnya bagi semua lapisan masyarakat. Pada tahun 20142018 diharapkan Indonesia masuk dalam Indonesia Broadband dan masyarakat masuk dalam kategori masyarakat pengetahuan ${ }^{4}$.

${ }^{4}$ Diakses dari

http://news.viva.co.id/news/read/196405-
Namun Berdasarkan hasil studi sejumlah praktisi e-Government di berbagai negara, secara pokok terdapat 3 (tiga) tantangan terbesar yang dihadapi oleh pemerintah maupun masyarakat dalam mengembangkan konsep e-Government di negaranya masing-masing, yaitu (Indrajit:2004:19) :

1. Tantangan yang berkaitan dengan cara menciptakan dan menentukan kanal-kanal akses digital (maupun elektronik) yang dapat secara efektif dipergunakan oleh masyarakat maupun pemerintah;

2. Tantangan yang berkaitan dengan keterlibatan lembagalembaga lain di luar pemerintah (pihak komersial swasta maupun pihak-pihak non komersial lainnya) dalam mengembangkan infrastruktur maupun superstruktur $e$ Government yang dibutuhkan; dan

3. Tantangan yang berkaitan dengan penyusunan strategi institusi terutama yang berkaitan dengan masalah biaya investasi dan operasional sehingga program manajemen perubahan e-Government ini

kemkoninfo-siapkan-road-map-indonesiadigital/0 
dapat berjalan dengan lancar sesuai dengan yang diinginkan.

Tantangan-tantangan diatas membuat kita harus jeli dalam melihat berbagai gejala, terutama perubahan paradigma dalam e-Government memiliki tuntutan yang cepat dan dinamis. Keterangan diatas juga menunjukkan bahwa pemerintah saja tidak bisa diandalkan untuk menjadi agen tunggal dalam percepatan perbaikan performa e-Government Indonesia. Pergeseran orientasi telah dan sedang dari Government Oriented kepada Citizen Oriented, selain itu Silo Resource atau sumber daya "silo" yang dipahami sebagai sebuah mentalitas yang kaku dan tertutup akan berubah menjadi Shared Resource atau sumber daya yang tersebarkan, dan layanan eletronik yang satu arah (tunggal) berubah menjadi Shared Service atau layanan yang tersebar dimana-mana (Anggono, 2015:12). Dari gambaran tersebut, maka perlu pihak-pihak lain agar dapat bekerja secara sinergis dan harmonis dalam tata kelola TIK pemerintahan di Indonesia. Secara eksplisit penulis akan menjelaskan siapa saja pihak-pihak yang patut berkolaborasi dalam mewujudkan digitalisasi dunia pemerintahan melalui penelusuran teori-teori terkait.

\section{Spektra Teoritika Pemerintahan}

Secara etimologis kata pemerintah dan pemerintahan ditarik dari kata "titah". Dari sudut leksikal berarti amanat, amar (al- 'amr), sabda, dan firman yang semuanya bermakna "perintah" (Endarmoko, 2006:647). Kata "titah" dapat dikatakan sejajar dengan kata gubernare (Latin/Spanyol), kybern (Greek/Yunani), dan govern (Inggris). Govern/ steering dalam bahasa latin adalah gubernare, sedangkan dalam bahasa Gerika (Greek/Yunani) adalah kybernan. Gubernare kemudian berubah menjadi Gubernantia. Sedangkan dalam bahasa Belanda, berasal dari kata besturen (mengemudiInggris: steering) di tambah kunde (kepandaian-Inggris: craft, skill) (Ndraha, 2003: xxii). Namun yang sering kita dengar dan gunakan dalam berbagai kegiatan akademik baik lisan maupun tulisan adalah derivasi (turunan) kata gubernantia yang kemudian menjadi cikal bakal (embrio) dari kata governance (govern+ance) yang berarti "pemerintahan" (peristiwa/ kejadian). Sedangkan kata government (govern+ment) adalah badan atau lembaga yang melakukan kegiatan dan aktifitas perintah-memerintah sehingga dari kegiatan dan aktifitas tersebut menghasilkan gejala, peristiwa, dan kejadian sebagai sebuah fenomena sosial yang tak terbantahkan. 
Menerusi pengertian pemerintahan diatas, sebenarnya kajian dan pembahasan tentang e-Government ini bermula dari dunia bisnis pada dekade 80-90an, dimana Douglas Holmes (2001) dalam bukunya yang berjudul e-Gov: eBusiness strategi for government yang mengatakan kelak akan terhubungnya Administration, Business, dan Citizen atau menyebutnya dengan istilah ABC's Government (Ndraha, 2003: 544). Selain Holmes, Rogers W'O Okot Uma dalam bukunya Electronic Governance: Reinventing Good Governance (tanpa tahun) yang pada intinya mengatakan bahwa perkembangan e-Government akan terus bergantung pada realisasi $e$ Business, dan e-Business yang dimaksud oleh Okot-Uma adalah $e$ Commerce atau perniagaan/ transaksi yang dilakukan secara elektronik (Ndraha, 2003: 543). Teori itulah yang menjadi root theory dari e-Government yang berasal dari dunia bisnis sehingga wajar bila dunia usaha/swasta menjadi leading dalam masalah ini.

Hal senada juga dikatakan oleh Richard Heeks (2001), bahwa perkembangan Teknologi informasi dan komunikasi yang baru dapat memberikan kontribusi yang signifikan terhadap tercapainya tujuan tata pemerintahan yang baik. Heeks bahkan menyebutnya sebagai tata kelola secara elektronis atau e-Governance bukan lagi sebagai e-Government (lembaga/ agen pemerintah saja). Pandangan Heeks tersebut menguraikan tiga kontribusi utama $e$-Governance, yaitu: Memperbaiki proses pemerintahan (eAdministration); Menghubungkan warga negara (e-Citizens dan $e$ Service); dan membangun interaksi eksternal (e-Society) (Heeks, 2001:1). Selaras dengan itu, dasar pemikiran tentang governance juga dapat mengacu kepada apa yang dikatakan Kooiman (2003: 4), yang juga mengemukakan hal yang hampir sama, bahwa governancel tata kelola dapat dilihat sebagai keseluruhan konsepsi teoritis tentang pemerintahan, dimana ia mendefinisikan pemerintahan sebagai sebuah totalitas interaksi publik dan juga aktor swasta yang berpartisipasi dengan tujuan untuk memecahkan masalah sosial atau menciptakan kesempatan masyarakat, menghadirkan institusi sebagai konteks yang mengatur interaksi, dan membangun fondasi normatif bagi semua aktivitas tersebut. Dalam konteks ini, Negara tidaklah mengalami kerugian, justru Negara adalah salah satu dari berbagai aktor potensial. Dengan demikian, negara (kemungkinan) hanya akan mengalami sedikit defisit kontrol saja namun tetap berpotensi memperoleh keuntungan dari segi sumber daya, keahlian dan pengetahuan (alih teknologi) yang 
ditawarkan oleh entitas lain (Kooiman, 1993: 2).

Pada perkembangan berikutnya, Carayannis et al (2012:1), menjelaskan muncul pula sebuah pendekatan model inovasi disebut Triple Helix yang berfokus pada hubungan universitasindustri-pemerintah dan dilanjutkan dengan model Quadruple Helix yang menyematkan Triple Helix dengan menambahkan "masyarakat berbasis media dan berbasis budaya" dan "masyarakat sipil" sebagai helix yang keempat. Dari model Quadruple Helix tersebut, yang mutakhir berkembang pula model inovasi Quintuple Helix yang bahkan lebih luas dan lebih komprehensif dengan mengkontekstualisasikan Quadruple Helix melalui penambahan helix dari perspektif "lingkungan alami masyarakat". Triple Helix mengakui secara eksplisit pentingnya pendidikan tinggi untuk inovasi. Quadruple Helix mendorong perspektif masyarakat pengetahuan, serta pengetahuan demokrasi untuk produksi pengetahuan dan inovasi. Dalam pemahaman Quadruple Helix, pengetahuan yang berkelanjutan juga memerlukan sebuah koevolusi dengan masyarakat yang berpengetahuan. Sedangkan Quintuple Helix sebagai pendekatan terkini menekankan transisi sosio-ekologis yang diperlukan masyarakat. Oleh karena itu, Quintuple Helix sensitif secara ekologis. Dalam kerangka model inovasi Quintuple Helix, lingkungan alami masyarakat dan ekonomi juga harus dilihat sebagai pendorong untuk memproduksi pengetahuan dan inovasi, sehingga dapat menentukan peluang bagi kemajuan sebuah negara melalui tata kelola pemerintahan yang terintegrasi. Hal ini bermakna bahwa pemerintahan kedepan harus mampu mengidentifikasi transisi sosioekologis sebagai tantangan besar bagi peta pembangunan masa depan. Quintuple Helix mendukung pembentukan situasi win-win solution antara ekologi, pengetahuan, dan inovasi yang mampu menciptakan sinergi antara ekonomi, masyarakat, dan demokrasi.

Berdasarkan pandangan teleskopik terhadap beberapa lapisan lensa teori diatas, sederhananya aktifitas governance atau pemerintahan atau juga dapat dimaknai dengan tata kelola sebagaimana yang telah dijabarkan diatas apabila ia didukung dengan teknologi sebagai enabler (alat bantu) akan menjadikan ia bertransformasi dari e-Government menjadi e-Governance yang mampu menata dan mengelola berbagai aktifitas pemerintahan menjadi lebih efektif dan efisien serta membawa manfaat besar lainnya. Ini menunjukkan bahwa e-Governance adalah realitas terkini, yang akan menjadi urgen dilakukan untuk masa depan sesuai dengan keadaan zaman yang menuntut sebuah perubahan yang 
bukan saja diperlukan oleh negaranegara maju tapi juga oleh negaranegara berkembang. Namun, sebagian besar inisiatif e-Governance hari ini umumnya masih mengalami obstacle bahkan terancam gagal dikarenakan negara menghadapi dua rintangan besar. Pertama, rintangan secara strategis untuk kesiapan: menyiapkan pra-kondisi yang teridentifikasi untuk e-Governance. Kedua, rintangan secara taktis untuk menutup kesenjangan realitas desain: menerapkan praktik terbaik dalam program e-Governance untuk menghindari kegagalan dan meraih kesuksesan. Bagaimanakah sebaiknya sikap kita? berikut beberapa butir pandangan yang dapat dijadikan sebagai pertimbangan.

\section{Pandangan dan Gagasan}

Sebagaimana yang telah dikatakan sebelumnya, bahwa selain tantangan dan rintangan dalam pelaksanaan e-Government, hasil-hasil penelitian sebelumnya pun sudah menunjukkan gejala yang sama. Penulis juga telah beberapa kali melakukan penelitian tentang performa e-Government Indonesia yang secara garis besar dapat dipilah menjadi dua aspek utama, yakni aspek TIK dan nonTIK. Namun ternyata dari beberapa pengalaman penulis dalam meneliti, membaca hasil-hasil penelitian dan mengamati secara langsung justru aspek non-TIK lah yang berpengaruh besar atau $70 \%$ penyebab kegagalan implementasi e-Government yang diantaranya adalah aspek kepemimpinan, budaya organisasi, sumber daya manusia, manajemen (terutama manajemen perubahan), rakayasa ulang proses urusan (business process procedures) aspek regulasi atau payung hukum, dan sisanya adalah aspek-aspek yang berkaitan dengan TIK baik hardware maupun software nya. Dalam dokumen Sistem infomasi Nasional (Sisfonas) yang dikeluarkan oleh Kementrian Komunikasi dan Informasi (2002), sebagaimana yang dikutip oleh Hasibuan dan Santoso (2005:47), bahwa manajemen perubahan berpengaruh sebesar $40 \%$, dan rakayasa ulang proses urusan (business process procedures) berpengaruh sebesar 35\%. Pada kondisi tersebut manajemen perubahan memegang peranan penting dalam implementasi sistem e-Government sebagaimana disebutkan pada pilar pertama dalam Inpres No. 3 Tahun 2003 tentang Kebijakan dan Strategi Nasional Pengembangan $e$ Government. Dalam konteks pengembangan sistem informasi, dikatakan bahwa manajemen perubahan (change management) merupakan proses dalam membantu individu terkait untuk mengadopsi dan beradaptasi dengan sistem yang akan digunakan. 
Akan tetapi, kendatipun manajemen perubahan (change management) dan rakayasa ulang proses urusan (business process procedures) yang merupakan aspek non TIK memberikan pengaruh besar terhadap kesuksesan implementasi $e$ Government, namun sebagai antitesa, penulis berpandangan bahwa aspek TIK bila dioperasikan dan dioptimalkan penggunaannya secara profesional dan proporsional justru akan mampu memberikan pengaruh atau parubahan terhadap perilaku dan resistensi manusia atau individu. Hal tersebut telah terbukti hari ini dimana mindset atau pola pikir manusia justru telah banyak digiring dan di "framing" oleh arus informasi yang bergerak deras melalui perkembangan TIK dan menjadi dasar atau alasan seseorang untuk mengambil sebuah tindakan. Salah satu contoh diantaranya adalah banyaknya orang memilih dan mengambil keputusan dalam hidupnya melalui persediaan atau "stock" informasi yang mereka miliki dari perangkat teknologi (gadget) pribadi yang mempunyai kemampuan dan daya jelajah tinggi dalam mengakses informasi dengan cepat dan tepat sehingga mereka memiliki data atau catatan dan refrerensi sebelum mengambil keputusan.

Berangkat dari sebuah pandangan filosofis, bahwa data merupakan sumber pengambilan keputusan dan kebijakan, data merupakan sumber penelitian dan pengembangan, data menjadi dasar dalam melakukan evaluasi, data merupakan bukti kinerja (sebagai output kemudian menjadi input perencanaan berikutnya), karena data merupakan bahan dasar atau bahan mentah sebagai catatan dari sebuah fakta dan peristiwa yang terjadi kemudian diolah menjadi sesuatu yang bermanfaat yang disebut informasi dan kemudian informasi itu dijadikan sebagai dasar dan alasan seseorang dalam mengambil keputusan. Berdasarkan life cycle tersebut, maka kedudukan data memiliki tempat yang penting dan strategis dalam implementasi e-Government sehingga perlahan mampu bertransformasi menjadi e-Governance. Artinya, berbicara e-Governance berarti berbicara e-Government, berbicara $e$ Government berarti berbicara TIK, berbicara TIK berarti berbicara tentang SIM (Sistem Informasi Manajemen), dan berbicara SIM berarti berbicara tentang sistem dalam mengelola dan mengatur informasi secara sistematis, dan berbicara tentang pengelolaan informasi secara sistematis berarti adalah berbicara tentang rekaman peristiwa (baca:data) apakah ia tercatat atau tidak. Berkaca dari pandangan filosofis tersebut, ternyata kejadian yang senyata-nyatanya terjadi adalah adanya ketidaksesuaian antara "data 
lapangan" dengan "data administrasi" terutama bagi lembaga/ instansi/ agen pemerintah. Terjadinya gap atau kesenjangan akan mengakibatkan kesalahan yang fatal dalam membuat perencanaan dan pengambilan keputusan. Oleh karena itu justru kita memerlukan perangkat TIK mutakhir dalam rangka mengumpulkan dan menertibkan arus data agar semua data tercatat/ tercover, terlindungi/ terjaga, dan dapat terpakai kapan saja bila diperlukan. Dikarenakan kemampuan manusia yang memiliki keterbatasan dalam mencatat dan mengingat maka Bank Data atau Data Center menjadi sesuatu yang urgen dalam memulai program e-Government sebelum menjadi sebuah tata kelola yang partisipatif dan kolaboratif dengan menjunjung prinsip-prinsip smart atau cerdas.

Solusi dari berbagai permasalahan-permasalahan

pemerintahan diatas memerlukan sebuah pendangan dan gerakan perubahan yang progresif dan komprehensif serta sesuai untuk masa sekarang dan masa yang akan datang. Sudah tidak zamannya lagi menggunakan solusi tradisional dalam menghadapi permasalahan yang muncul bahkan yang belum munculpun harus dapat diprediksi. Sistem ini bermula dari memanfaatkan teknologi Big Data sebagai sentralnya, dimana sumber data didapat dari berbagai peralatan teknologi pendukungnya sebagai alat bantu. Berdasarkan pemahaman tersebut, maka perlu sinergitas dengan semua pihak, terutama swasta yang memiliki kreatifitas sekaligus finansial melalui percepatan pembangunan infrastruktur bersama seperti pusat data bersama (shared DataCenter) jaringan Fiber Optic bersama (shared FO network) dan Tower pemancar bersama (shared Tower) antara swasta dan pemerintah. Mengapa ini urgen dilakukan? Bila dibreakdown menggunakan cost and benefit analysist, maka program $e$ Government memerlukan kesiapan yang matang dalam berhagai hal dan keikutsertaan berbagai pihak (pemerintah-swasta-

akademisi/universitas-profesionalmasyarakat) sebagai sebuah kesatuan utuh dari governancy/ governability (kepemerintahan) yang terpadu dan melibatkan semua pihak. Keadaan tersebut dapat penulis gambarkan dalam sebuah bangunan TIK pemerintahan dibawah ini: 


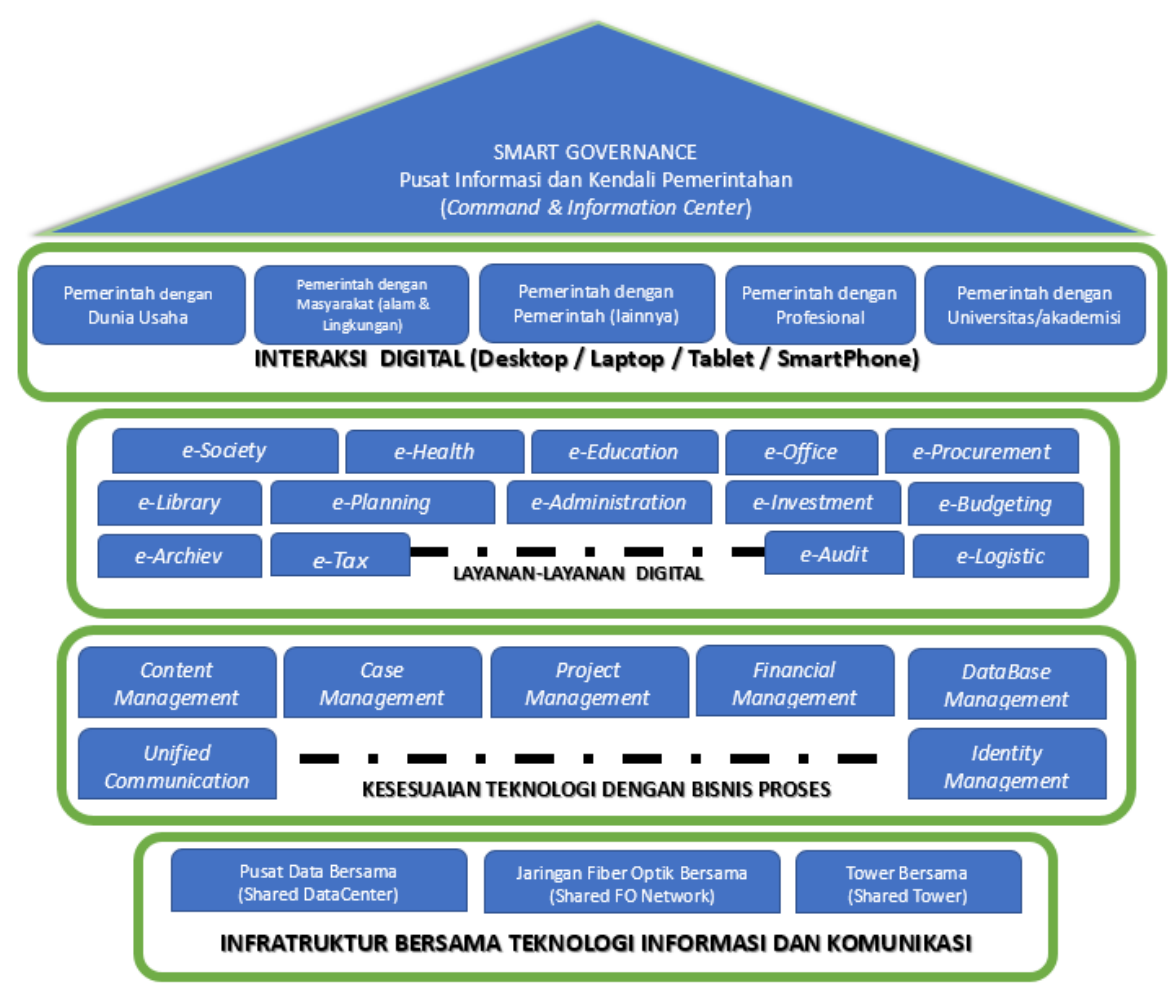

Gambar 1. Konsep Integrated Smart Governance

Sumber : Gafar dan Madrus (2016). Makalah Disampaikan Pada Seminar Pekanbaru Menuju SmartCity.

Komponen dasar dari bangunan diatas adalah Infrastruktur bersama atau komponen tempat data tinggal (rumah data) dan tempat data berpindah (jalur data). Komponen diatasnya adalah kesesuaian teknologi dengan business process (proses urusan) merupakan aplikasi umum yang sudah dibuat dan dapat digunakan karena sebagian fiturnya telah sesuai atau dapat disesuaikan kembali dengan kebutuhan penatakelolaan pemerintahan diberbagai tingkat pemerintahan (pusat-daerah). Sedangkan komponen diatasnya lagi adalah aplikasi-aplikasi layanan digital yang memang tidak ada dipasaran, namun harus dibuat mengikuti kebutuhan, dan kalaupun sudah ada harus dilakukan modifikasi sana-sini disesuaikan dengan kondisi lapangan dan aturan yang berlaku. Sedangkan komponen berikutnya adalah komponen interaksi yang merupakan elemen-elemen pengguna dari sistem Smart Governance. Terakhir adalah komponen yang digunakan oleh beberapa orang tertentu yang digunakan untuk menjelaskan, memonitor dan mengendalikan berbagai permasalahan dalam sebuah 
pusat kendali dan informasi yang dapat digunakan sebagai dasar pengambilan keputusan oleh decision maker atau Pembuat Kebijakan.

\section{KESIMPULAN}

Ilmu pengetahuan tanpa falsafah adalah fakta tanpa perspektif dan penilaian yang tak dapat menyelamatkan kita dari malapetaka dan keputusasaan. Ilmu pengetahuan memberi kita pengetahuan, tapi hanya falsafah yang bisa memberi kita kebijaksanaan. Pembangunan berkelanjutan disuatu negara membutuhkan paradigma utama sebagai seperangkat nilai filosofis dan inti dalam mengubah dan memperbaiki kondisi di semua wilayah kehidupan. Pada perspektif etika global, pembangunan didorong oleh empat kekuatan yaitu Politik, Ekonomi, Lingkungan Hidup, dan bahkan Agama. Meski berbeda satu sama lain, namun keempat kekuatan tersebut menuju pada tujuan yang sama, penulis menyebutnya dengan "Green Paradigm" melalui pemanfaatan Teknologi Informasi dan Komunikasi (TIK) dalam kegiatan tata kelola di era digital yang berwawasan lingkungan. Dalam kehidupan sehari-hari, warna hijau memberi sentuhan teduh dan sehat, dimana warna hijau berperan pada proses produksi oksigen yang memang sangat dibutuhkan oleh semua makhluk. Artikel ini telah berupaya menyatukan berbagai konsep dan asas yang akan menjadikan kita "tau diri" dari mana kita (manusia) berasal dan kemana akan kembali, dipadupadankan dengan perkembangan teoriteori baru menjadi suatu pendekatan yang komprehensif dalam mengelola sebuah negara modern sambil tetap menjaga keseimbangan alam.

Pada akhirnya, pendekatan ini diharapkan akan menghasilkan bentuk ideal yang bukan hanya mengacu pada prinsip Good Governance tetapi juga bergerak kearah Great Governance yakni terkoneksinya semua lembaga/ institusi/ agen pemerintah, sektor swasta, masyarakat sipil, akademisi/ universitas, dan kalangan profesional melalui pemanfaatan TIK secara profesional dan proporsional serta memegang prinsip pembangunan berkelanjutan sehingga menjadikan ia bukan hanya Good, Great, tetapi juga menjadi prinsip Green Governance dimana semua akses untuk memenuhi kebutuhan hidup akan mudah didapat dan mengarah pada suatu penciptaan harmoni antara yang "memerintah" dengan mereka yang "diperintah" sehingga segala hak dan kewajiban dalam bernegara dapat terlaksana dengan cepat, tepat, adil, berimbang, dan berkesinambungan. Prinsip pemerintahan yang demikian penulis sebut sebagai "Health Governance". 
DAFTAR PUSTAKA

Anggono. Ibenk Dwi. 2015. eGovernment Indonesia Update 2015 - 2019. Kementrian Komunikasi dan Infomasi Republik Indonesia. Melalui http://www.unosd.org/content/d ocuments/1114eGovernment $\%$ 20Indonesia\%20update\%20for \%20UN\%20-\%20Seoul\%202428\%20Maret\%202015.pdf.

(Diakses pada 30-03-2017)

Carayannis,

Elias G,

Thorsten D Barth and

David FJ Campbell. 2012. The

Quintuple Helix innovation model: global warming as a challenge and driver for innovation. Journal of Innovation and Entrepreneurship - A Systems View Across Time and Space 2012 https://innovationentrepreneurship.springeropen. com/articles/10.1186/21925372-1-2. (diakses pada 10-012017)

Endarmoko, Eko. 2006. Tesaurus Bahasa Indonesia. PT. Gramedia Pustaka Utama: Jakarta

Gafar, T. Fahrul Gafar dan Said Madrus. Pekanbaru Menuju SmartCity. Makalah disampaikan pada seminar Forum Pekanbaru Smart.
Premier Hotel Pekanbaru, 21 November 2016

Hasibuan dan Santoso. 2005.

Standardisasi Aplikasi E-

Government Untuk Instansi

Pemerintah. Prosiding

Konferensi Nasional Teknologi

Informasi dan Komunikasi

Indonesia. ITB, 3-4 Mei 2005

Heeks, Richard. 2001. Understanding e-Governance for Development. Institute for Development Policy and Management. Manchester: UK

Indrajit, Ricardus Eko. 2004. Electronic Government : Strategi Pembangunan dan Pengembangan Sistem Pelayanan Berbasis Teknologi Digital. Andi: Yogjakarta

Kooiman, Jan. 1993. Modern Governance: New GovernmentSociety Interactions. Sage Publications: London

Kooiman, Jan. 2003. Governing as Governance. Sage Publication: London

Ndraha, Taliziduhu. 2003. Kybernology (Ilmu Pemerintahan Baru) Jilid 1. Rineka Cipta: Jakarta

Pemerintah Siapkan Road Map Indonesia Digital. Melalui http://news.viva.co.id/news/rea d/196405-kemkoninfo-siapkanroad-map-indonesia-digital/0. (diakses pada tanggal 12 juni 2015). 
United Nations e-Government Survey 2014 e-Government For The Futre We Want). Melalui https://publicadministration.un. org/egovkb/Portals/egovkb/Doc uments/un/2014-Survey/E-

Gov_Complete_Survey-

2014.pdf (diakses pada 20-032017).
United Nations e-Government Survey 2016 e-Government in Support of Sustainable Development. Melalui https://publicadministration.un. org/egovkb/en-us/Reports/UNE-Government-Survey-2016. (diakses pada 20-03-2017). 